\title{
Worldwide Implications of Parental Love and Lack of Love on Children's and Adults' Psychological Adjustment and Maladjustment: Meta-analytic Evidence
}

\section{Abdul Khaleque}

University of Connecticut, USA

\section{Short Communication}

Interpersonal acceptance and rejection theory (IPARTheory) predicts that perceived parental acceptance (love) and rejection (lack of love) have universal consequences on children's and adults' psychological adjustment and maladjustment [1]. To test these predictions, so far 12 meta-analyses have been conducted [2]. These meta-analyses are based on a total of 551 studies conducted over period of 41 years (1975-2016). These studies represented an aggregated sample of 149,440 respondents including children and adults. The respondents were taken from 31 countries in five continents (i.e., Africa, Asia, Europe, North America, and South America). The countries are: Bangladesh, Barbados, China, Colombia, Croatia, Czechoslovakia, Egypt, Estonia, Finland, Greece, India, Iran, Jamaica, Japan, Kuwait, Mexico, Nigeria, Pakistan, Peru, Poland, Portugal, Puerto Rico, Romania, South Korea, Serbia, Spain, St. Kitts, Sweden, Turkey, Ukraine, and the USA. The overall results of these meta-analyses confirmed that there are significant relations between parental love and psychological adjustment, and parental lack of love and psychological maladjustment of children and adults regardless of differences in races, ethnicities, cultures, age, gender, and geographical boundaries [3]. Results also showed that perceived parental love accounts universally about $26 \%$ of variability in children's psychological adjustment and about $21 \%$ of variability in adult's psychological adjustment [4].

Moreover, serious and chronic parental lack of love in childhood appears to have severe and longer-lasting emotional, social, cognitive, behavioral, and neurobiological effects on children and adult offspring than do perceived lack of love in other attachment relationships throughout life [5].

The majority of studies that assess the relation between parental lack of love and psychological maladjustment tend to focus predominantly on the influence of mothers' behavior even though fathers' are often as strongly implicated as mothers in many developmental outcomes. A large number of studies show that perceived paternal love often has as strong or even stronger implications than perceived maternal love for children's positive developmental outcomes, including psychological adjustment [6]. Results of a meta-analytic review have shown that father love has a significantly stronger relation with children's psychological adjustment than mother love cross-culturally [7]. However, perceive maternal lack of love has significantly stronger relations with children's psychological maladjustment than perceived paternal lack of love [8].

To sum up, nearly 4,000 worldwide studies on the implications for love and lack of love of children by parents suggest the following important messages for professionals and practitioners globally [9].

1. Children's feelings of being loved, cared, and appreciated by parents are likely to have greater developmental outcomes than any other single parental influence.

2. As every cultural and ethnic group has its own ways of communicating love and affection, parents of a particular culture should find culturally appropriate ways to communicate love, warmth, and affection. Moreover, parents should avoid behaviors that indicate coldness, hostility/aggression, and indifference/neglect that induce a feeling of rejection in children.

3. Compared to children who feel loved, children who feel unloved are likely to develop a pattern of psychological maladjustment, and personality dispositions including hostility/aggression, dependence, low self-esteem, low self-adequacy, emotional unresponsiveness, emotional instability, negative worldview, anxiety, and insecurity.

4. Children who perceive themselves to be rejected or unloved are also likely to develop behavioral problems, conduct disorders, delinquency, substance abuse, and depression.

5. Father's love related behaviors often have as strong or even stronger implications for children's psychological adjustment, personality and socio-emotional development than do mother's love.

\section{References}

1. Rohner RP (1986) The warmth dimension: Foundations of parental acceptancerejection theory. Beverly Hills.

2. Khaleque A, Ali S (2017) A critical review of meta-analyses of research on interpersonal acceptance-rejection theory: Constructs and measures. Journal of Family Theory and Review.

3. Khaleque A (2015) Parental acceptance and children's psychological adjustment. In: Kirkcaldy B (ed.) Promoting psychological well-being in children and families. Houndmills, Basingstoke.

4. Khaleque A, Rohner RP (2002) Perceived parental acceptance-rejection and psychological adjustment: A meta-analysis of crosscultural and intracultural studies. Journal of Marriage and Family 64: 54-64.

5. Rohner RP (2016) Introduction to parental acceptance-rejection theory methods, evidence, and implications

6. Rohner RP, Veneziano RA(2001) The importance of father love: History and contemporary evidence. Review of General Psychology 5:382-405.

7. Khaleque A, Rohner RP (2012) Pancultural associations between perceived parental acceptance and psychological adjustment of children and adults: A meta-analytic review of worldwide research. Journal of Cross-Cultural Psychology 439: 784-800.

*Corresponding author: Khaleque A, Adjunct Professor, Department of Human Development and Family Studies, University of Connecticut, USA, Tel: 860486 6291; E-mail: abdul.khaleque@uconn.edu

Received December 01, 2017; Accepted January 05, 2018; Published January 16,2018

Citation: Khaleque A (2018) Worldwide Implications of Parental Love and Lack of Love on Children's and Adults' Psychological Adjustment and Maladjustment: Metaanalytic Evidence. J Ment Disord Treat 4: 150. doi:10.4172/2471-271X.1000150

Copyright: (c) 2018 Khaleque A. This is an open-access article distributed under the terms of the Creative Commons Attribution License, which permits unrestricted use, distribution, and reproduction in any medium, provided the original author and source are credited. 
Citation: Khaleque A (2018) Worldwide Implications of Parental Love and Lack of Love on Children's and Adults' Psychological Adjustment and Maladjustment: Meta-analytic Evidence. J Ment Disord Treat 4: 150. doi:10.4172/2471-271X.1000150

Page 2 of 2

8. Khaleque A (2017) Perceived parental aggression, and children's psychological maladjustment, and negative personality dispositions: A meta-analysis. Journal of Child and Family Studies 26: 977-988.
9. Rohner RP (1986) The warmth dimension: Foundations of parental acceptancerejection theory. Beverly Hills. 